\title{
Why do Islamic Banks Concentrating Finance in Murabaha Mode? Performance and Risk Analysis (Sudan: 1997-2018)
}

\author{
Omer Allagabo Omer Mustafa ${ }^{1}$ \\ ${ }^{1}$ Assistant Professor of Economics, Banking \& Finance, Program of Banking \& Financial Studies, Secretary for \\ Academic Affairs, Sudan Academy for Banking \& Financial Sciences -Sudan
}

Correspondence: Omer Allagabo Omer Mustafa, B.O.BOX 1880 Khartoum, Sudan. E-mail:

omergabo78@sabfs.edu.sd

Received: May 19, 2020

doi:10.5539/ibr.v13n7p208

Accepted: June 15, $2020 \quad$ Online Published: June 23, 2020

URL: https://doi.org/10.5539/ibr.v13n7p208

\begin{abstract}
During 1997-2018, Islamic Banks (IBs) in Sudan provided finance by Murabaha mode to their clients with more than $45 \%$ on average. This position raises questions of why do IBs concentrating finance in Murabaha Mode rather than other modes? is this concentration implying risk and does it have influence on the financial performance of IBs? This study aimed to discusses the reasons and answer these questions. Nonperforming loan(NPL), Murabaha to gross finance, Musharaka to gross finance, Mudabaha to gross finance and Salam to gross finance were used to indicate the credit risk. Return on Equity (ROE) was used to indicate the financial performance of IBs. Ordinary least squares technique was employed to determine the trend of relations between the variables. The main results of the study show that there is an important positive relationship between the NPL and provision finance by both Murabaha and Mudaraba modes. Whereas were a negative with both Musharaka and Salam. Moreover, it's found that there is strong negative relationship between NPL and ROE. The main reason for the expansion granting finance by Murabaha mode is that IBs are heavy rely on collaterals and in case of clients' failure to pay, they sell collaterals to keep their financial performance safety. The study strongly recommends IBs importance of diversify the granting finance among Islamic modes of finance to avoiding the risk of concentration the finance by Murabaha mode. Furthermore, monetary authority in Sudan need to keep IBs aware with the risk associated with Islamic modes, especially Murabaha.
\end{abstract}

Keywords: Murabaha mode, financial performance, credit risk, Islamic banks, Sudan

\section{Introduction}

One of the major different between Islamic finance and conventional is to that Islamic banks(IBs) have variety in provides their customers with required finance using different Islamic modes of finance includes murabaha, musharaka, mudaraba, Bay' al- Salam, etc. Whereas conventional used only interest rate as a cost of borrowing money. In its annual reports for the duration 1997-2018, The Central Bank of Sudan (CBOS) continued to report that provision of finance in murabaha mode continues to represent approximately $50 \%$ of the total finance. This study tries to explore and discusses the reasons behind the phenomenon so as to examine the potential influence of the concentration of granting finance by Murabaha on the financial performance of IBs.

\section{Theoretical Framework and Literature Reviews}

\subsection{Basis, Nature and Scope of Islamic Finance}

Islamic banking is a financial system with key aim is to fulfil the instructions of the Holy Quran (principles of the Muslims' holy book). Islamic rules mirroring the orders of God and this regulates all sides of a Muslim's life and henceforth Islamic finance is associated to spiritual values and community justice (Nedal, 2004). Several definitions of Islamic finance are mentioned in the literatures of which includes; Alsadek, H.and Andrew, C (2007) defined Islamic finance as follows: "Islamic finance is a financial service principally applied to complies with the canon of Islam (Shari'ah or Islamic law). In turn, the main sources of Shari'ah are the Holy Quran, Hadith, Sunna which derived from life of the Prophet Mohammad (peace be upon him), Ijma (It is the agreement of all Muslim scholars on something), Qiyas and Ijtihad (It is the conclusion and deduction of legal provisions from its evidence" while Warde (2010), in its definition of Islamic banks stated that "those that are based, in their goals and processes, on Quran's values and teachings". This means that Islamic financial institutions are not just banks, but 
also other types of institutions that apply Shari'ah principles.

Islamic banks can be defined as a financial institution that ;(a) abides by shariah principles in all of its activities through its role as a financial intermediary between savers and investors ;(b) provides banking services within the framework of legitimate contracts; and (c) achieves a balance between economic and social return(Alharbi,2015). Islamic finance refers to the types of investments that are permissible under Shari'ah law.

In field of Islam is not allowed to use riba (interest, usury or fixed return), prohibition of gharar (uncertainty), speculation and gambling and money not carry any intrinsic value in itself among the financial transactions, while it is allowing to profit-and-loss sharing (PLS) and hereafter risk distribution and sharing (Mehmet ,2008).

\subsection{A Brief Definition of Islamic Modes of Finance}

Through the principles of Islamic finance, Islamic modes of financing are designed to facilitate financing according to Islamic law. (Abdul, 1999). The inhibition of interest rate in any operation related to Islamic banking increases the problem of how foundations, corporations, institutions, banks, etc., will work in an Islamic environment compared to conventional, where interest directs capital towards economic sectors causing excess or shortage of savings and liquidity. By applying PLS rule, IBs has various ways to granting finance to the users of funds involves the following main modes; Mudaraba and Musharaka. Mudaraba it is inactive or a passive partnership and it considered as type of venture capital and participatory funding while Musharaka (sometimes called Shirkah) it is active partnership or sharing capital between bank and customer (Mustafa,2019, p.16). Beside the main modes Islamic Banks provides some secondary modes like Murabaha, Ijarah, Ijarah wa iqtina', Salam, Istisna, Sukuk and Qard Hassana. Table 1 shows the concise definitions of the secondary modes.

Table 1. Simple Definitions of the Secondary Islamic Modes of Financing

\begin{tabular}{ll}
\hline Mode & The bank sells an asset or commodity to client in range of principal finance (cost) plus service \\
Murabaha & charge. The cost and charge must be known for both bank (seller) and client (purchase order). \\
The bank Lease (rent) an asset to client on its demand. & $\begin{array}{l}\text { Than } \\
\text { Ijarah wa iqtina } \\
\text { the ends to fully own asset). }\end{array}$ \\
Salam & $\begin{array}{l}\text { Forward delivery contract or forward financing transaction. it enables client to get finance in } \\
\text { advance. the client delivers the goods to bank in a certain future period in accordance with the }\end{array}$ \\
& contract. This mode usually used in agriculture area. \\
Istisna & Financing for commissioned or pre-ordered production or contractual production. \\
Sukuk & It is asset based Islamic bonds. \\
Qard Hassana & It is Good loan with zero interest rate. It enables customer to borrowing money without pay interest. \\
\hline
\end{tabular}

Source: Author own.

The difference between the main and the secondary Islamic modes of financing is that in the main modes, the bank's rate of return does not get determined in advance and depends rather on the ultimate yield of the business.

\subsection{Steps of Implementing of Murabaha Mode in Islamic Banks}

Iqbal and Mirakhor (2011) stated four steps as a mechanism for conducting murabaha in Islamic banks as follow:

1) The possible purchaser requests the merchant to quote a price for the goods required.

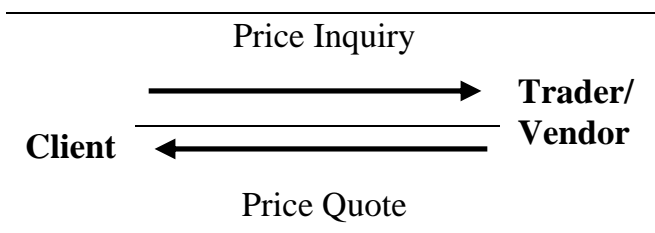

Figure 1. First Step of Conducting Murabaha Contract in Islamic Banks

Source: Iqbal and Mirakhor (2011)

2) In light of the first step, the purchaser makes a contacts with its bank and promising to buy the goods, if the bank buys the same goods from the merchant and resells them to its customer at the cost plus a profit to be 
agreed upon mutually. At this stage, the bank would consider entering into a murabaha contract, impose the conditions and collaterals for the acceptance.

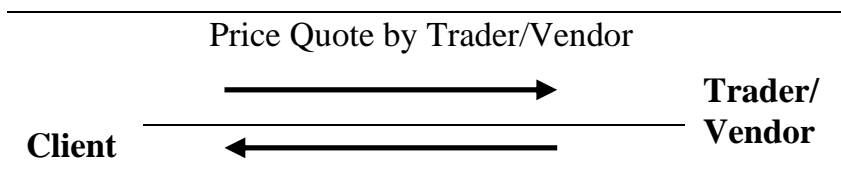

Promise to buy at Cost-Plus-Profit

Figure 2. Second Step of Conducting Murabaha Contract in Islamic Banks

Source: Iqbal and Mirakhor (2011)

3) The bank as financer paying to purchase and deliver the goods from the merchant. Usually bank appoint the customer as his agent to accept the delivery on his behalf. Moreover, the bank is still the holder of the goods, a murabaha contract is signed between the parties includes charged and procedures. The contract is finished by agreeing on the mode of payment (lump sum or via instalments). The bank requests client to present collateral like real-estate against credit risk or default in payment.

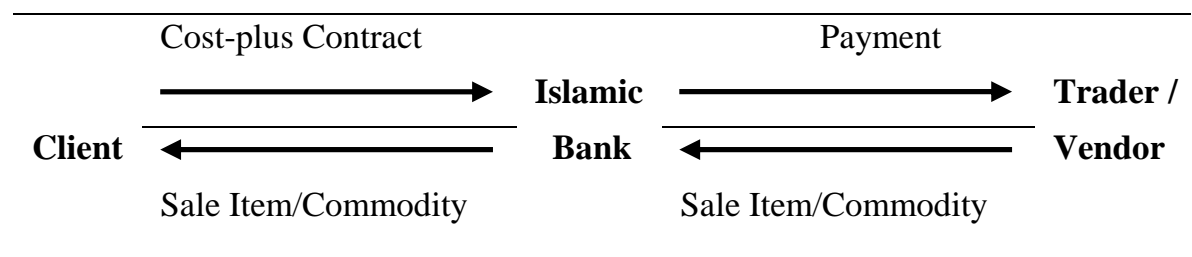

Figure 3. Third Step of Conducting Murabaha Contract in Islamic Banks

Source: Iqbal and Mirakhor (2011)

4) In this step, the client must fulfil the payment to the bank as its states in the contract. The payment should comprise the cost in addition to a profit margin (return on investment).

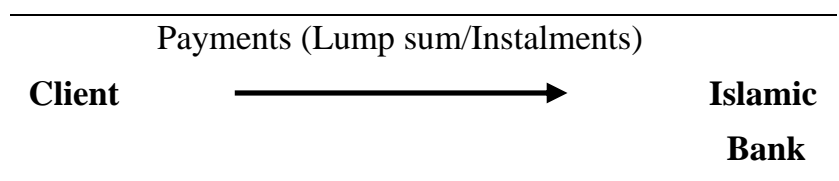

Figure 4. Fourth Step of Conducting Murabaha Contract in Islamic Banks

Source: Iqbal and Mirakhor (2011)

There are some conditions for murābaha contract that IBs must fulfill to ensure that the contract does not contain riba(interest) includes:

- The asset is in existence at the time of the sale contract.

- The asset is legally owned by an Islamic bank when it is sold.

- The asset is intended to be used by the buyer for activities or business permissible by the Sharī ah.

- In the event of late payment, there is no penalty fee or increase in price in exchange for extending or rescheduling the date of payment of accounts receivable, irrespective of whether the debtor is solvent or insolvent.

In light of the mentioned conditions, the murābaha contract is exposed to Sharī'ah non-compliance risk if the contract fails to satisfy the essential requirements of a valid sale contract or it has attached external factors that may hinder its validity (Accounting and Auditing Organization for Islamic Financial Institutions [AAOIFI], 2010, pp. 521-532). 


\subsection{Risk Associated with Modes Used to Granting Islamic Finance}

Islamic banks are obligated to follow the Sharia principles in all their operations, and therefore dealings with financial transactions may exposure them to the following four common risks:

\subsubsection{Credit Risk}

The credit risk is defined as inability of customer to repay the principal (the amount granted to the businessperson or the financing capital) to the provider of finance (the bank). In other words, the applicant of finance in the payment system became totally unable to meet its financial obligations to the Islamic bank at the time come due or at any upcoming time. In both of Mudaraba and Musharaka contracts, the bank will be applying the PLS rule thus partnership is subject to loss of its investment capital. As for the Murabaha, Islamic bank does not allow the implement the PLS rule, but according to the contract the customer alone bears the loss because it is a buyer of the commodity not a partner in the capital (Islamic Financial Services Board [IFSB], 2005).

\subsubsection{Market Risk}

It is a common type of risk related to instability of market price of assets or liabilities. The value of assets may possibly decrease over a certain time period for the following reasons; overall economic changes, currency exchange rates fluctuations, volatility of commodities price and other actions that influence the stability of the market. Under Murabaha, the market risk is fixed along time of the contract. When banks are faced upward movement of the market price of assets under Murabaha contract, they become unable to benefit from such an increase which is called mark-up risk. Moreover, the market risk is predominant in the case of Bay' al- Salam, where the IBs bears the risk of taking to cope with instable environment where the commodities prices could fluctuate significantly between the delivery, carriage time goods and the real sale at the current market price (IFSB,2005). IBs may also possible to exposure to exchange rate risk when premiums are due but not received.

\subsubsection{Securities Risk}

Some IBs are acceptable providing or granting the finance to their customers in one of Islamic modes of financing against taking the securities such share and Islamic bonds (Sukuk) as collateral. During the maturity time, the banks keeping securities, therefore if the market price of securities changes, the securities risk will take place. This risk related to investing in negotiable and marketable securities where the rate of return on securities is determined by business performance rather than pre-determined fixed rate of return.

\subsubsection{Liquidity Risk}

Islamic banks probably facing two types of liquidity risk include; 1) From the aspect of client: liquidity risk occurs when a client in a payment system will be unable to meet its financial obligations or became incapable to pay back instalments to the banks timely due to insufficient funds. But possibly it's able to repayment totally at near future time. 2) From the aspect of bank: its refers to incapability of IBs to cover their expected and unexpected current financial obligations (such meet costumers cash withdrawal from their accounts), future cash flow needs and collateral requirements. According to IFSB (2005), the liquidity risk rises due to limited obtainability of Shariah compatible money market, the absence of true inter-bank money market, not fully formed secondary markets and money held in demand accounts is largely kept in the form idle cash because of lack of illiquid short-term instruments.

\subsubsection{Operational Risk}

According to Abdullah, M., Shahimi, S. and Ghafar Ismail, A. (2011), operational risk is defined as the probable loss causing from inadequate or failure of internal procedures in Islamic bank, persons and system or external events or mistakes by human operators. (Basel Committee on Banking Supervision[BCBS] 2001) determined the sources of operational risk consist of: (1) Internal counterfeiting; (2) Fraud outside the institution; (3) Business ethics, Behaviors of employment and workplace security; (4) Customer, output and business practices; (5) Harm to tangible assets; (6) Business interruption and system down and; (7) Processing of business procedures, implementation, distribution and operations management.

\subsubsection{Shari'ah Non-Compliance Risk}

This type of risk is a unique for IBs. The IFSB and (International Shari'ah Research Academy for Islamic Finance [ISRA], 2016) defined the Shari'ah Non-Compliance Risk as "the risk arising from the failure of IBs to comply with the Shari' ah rules and principles determined by the Shari' ${ }^{-}$ah board or the relevant body in the jurisdiction in which the IBs operates". The failure to comply with such rules will result in the operation being invalid, and later the revenue cannot be acquired (IFSB, 2012). 


\subsection{Literature Review of Islamic Finance}

Kireyev, A (2001) reviewed the experience of financial reforms in Sudan with a view to assessing their macroeconomic impact and to shedding light on the question why such reforms have not yet brought about visible improvements in financial intermediation. The study concludes that deficiencies in the reform design, institutional weaknesses, shallow financial markets, shortcomings of the Islamic mode of finance, and strong seasonality remain key factors that constrain financial intermediation in Sudan.

Rosly, S. (2005). discussed that IBs prefers used of Murabaha financing for the following reasons (a) Murabaha rate of return is predetermined, fixed and continues;(b) Trade financing does not require much efforts to monitor, cooperate or evaluate like investment based financing and ;(c) Risk of default is relatively low. Whilst for the entrepreneurs, Murabaha is preferable due to its ;(i) Fixed rate of return along payment period ;(ii) No charge for late payment/default and ;(iii) Treating an asset being purchased as collateral.

Loghod, H. (2005) studied and compared the performance of the two banking classes (Islamic and Conventional) in terms of profitability, liquidity and structure for the period (2000-2005) in Gulf Cooperation Council countries. The results of the study confirmation that there no major differences in terms of profitability. Moreover, IBs have a smaller of exposed to liquidity risk.

Mohsin, Magda, I. (2005) discussed the practice of Islamic banking in Sudan to shows how successful of Islamic system is achieved. The study found that, banking system in Sudan is compiles with Shari' ${ }^{\top}$ ah rules and succeeded in minimizing dealing with riba through resorting to murabaha, mudaraba, musharaka, ijarah, etc.

Samad, A., Gardner., and Cook. (2005) identified the relative importance of various Islamic financial products, in theory and in practice, by examined the financing positions of the Bank Islam Malaysia (Berhad) and the Bahrain IBs. The results found that, mudaraba and musharaka are the most distinct and their unique characteristics make IBs and Islamic financing viable alternatives to the conventional interest-based financial system.

Hassan and Girard (2010) examined the performance of seven indices chosen from the Dow Jones Islamic Market Index family and discover no substantive difference in performance from their conventional counterparts. The study found similar risk-reward ratios and diversification benefits for Islamic and conventional indices.

Swartz, Nico, P. (2012) tried to review the guiding principles for risk management and problems linked with the risks environment increasing from the utilization of funds of Islamic financial institutions. The research concluded that the system of Islamic finance is mainly justice-based and PLS rule.

Walkshausl, C,. and Sebastian, L. (2012) compared the financial performance of risk-adjusted Islamic indices with that of conventional indices for 2002-2012. The results found that IBs indices generally outperform in developed markets but underperform in emerging markets.

Elgadi, Entissar, M. (2016) investigated the interrelationship between performance, measures and determinants of Sudanese IBs (2005-2013). The estimated results of the model prove that PLS role of Modaraba and Mosharaka have a significant positive impact on profitability.

Mansour, I. and Sa'adeh, Y. (2016) evaluated murabaha in IBs in Jordan - especially Murabaha which represents about $40 \%-80 \%$ of its activities - by comparing IBs operations with Islamic shari'a provisions for Murabaha. The results found that, IBs practice the same activities of conventional banks. This is evident in Murabaha to the order of the purchaser which represents $40 \%-80 \%$ of IBs activities.

Ismal, R. (2017) Assessed the moral hazard problem in Murabaha financing in Islamic banks. The study found that, price volatility of the good being financed opens a chance for entrepreneurs to gain profit by pretending to be default (moral hazard) so, Islamic bank can mitigate it through appropriate bank's investigation and charging some cost as well as penalty.

Nouman, M., Karim Ullah, K. and Gul, S. (2018) tried to answer the question of why IBs tend to avoid participatory financing? The results found that participatory financing arrangements including Musharaka and Mudaraba are the essence of Islamic banking and represent the true spirit of Islamic banking and finance. Therefore, IBs are expected to allow and promote participatory financing.

Moussa, F. and Zaiane, S. (2018) discussed the risk's determinants of Islamic Banking in the Mena Countries during the Global Financial Crisis and the Arab Spring Period (2000-2013). The results reveal that bank size, capital adequacy, liquidity, diversification and specialization ratios are the major factors affecting the stability of IBs.

Grassa, R. (2018) investigated the relationship between banking risk and Islamic financial products diversification for IBs in Gulf Cooperation Councilse Countries (2002-2008). The study found that, IBs expanding into 
Profit-Loss-Sharing products present higher risk and higher insolvency risk than banks that invest less in this kind of arrangement.

Several studies have discussed issues of the financial performance of IBs in general, nevertheless, there is urgent need in Sudan to studying issues related to Islamic modes of finance separately. This study mainly aims to empirically examine the question of why IBs in Sudan prefers use of Murabaha mode instead of other modes during the period (1997-2018).

\subsection{Statement of the Problem}

In murabaha contract the IBs makes prompt delivery of assets (goods) but if client fails to make timely payment. The bank is in no position to takings effective measures or actions to cover its dues nor can it charge interest (forbid in Islam) or impose punishment on the outstanding balance. In case of the customer's total failure to pay the murabaha instalments (the bank will be exposed to credit risk). The bank's only way to recover the financing is to sell or liquidate the collaterals taken from the customer (real estate, building, securities, etc.). It is also possible for a bank to be exposed to market risk (price risk occurrence when the value of goods or collaterals may decline over a certain period because of economic fluctuations such as volatility in the exchange rates and commodities price) related to the collaterals and underlying asset resulting in deterioration the profitability thus the financial performance of the bank. In light of CBOS's reports (1997-2018) as mentioned in the introduction, the problem of the research is derived from the following questions of why do Islamic banks concentrating finance in murabaha mode? What is the expected risk and potential effects on the financial performance?

\subsection{Importance of the Research}

The research highlights the practical importance of analyses the expected effects on financial performance and the risks that IBs in Sudan might exposed, especially with the continuous of expansion granting financing in murabaha mode to more than half of the total bank financing as stated by the CBOS (2018, p.63).

\subsection{Objectives of the Research}

Mainly, the study purposed to examine empirically the expected effects of murabaha concentration and risk on the financial performance of IBs in Sudan (1997-2018). Moreover, to reach the following sub-objectives:

1) To offer a brief definition of Islamic modes of finance.

2) To provide a concise description of risk associated with Islamic modes of finance.

3) To discuss the reasons leading IBs to concentrate finance in murabaha mode.

4) To assess the efficiency of the monetary authority in controlling banking finance.

5) To clarify the role of IBs in developing economic sectors in Sudan.

\subsection{The Research Hypotheses}

The study tries to test the following hypotheses:

1) There is a significant relationship between the nonperforming loans and provision finance in Islamic modes.

2) There is a significant relationship between nonperforming loans the finance performance of Islamic Banks.

\subsection{The Methodology of the Research and Data}

To explore why do Islamic banks concentrating finance in murabaha mode and to find the link between the financial performance of IBs and nonperforming loans, ordinary least of square method was runes. Data of the study were gathered from annual published reports of the Central Bank of Sudan. Augmented Dickey-Fuller and Unit Root tests were applied to ensure data stationarity.

\section{Financial Performance of Islamic Banks in Sudan (1997-2018)}

\subsection{Analytical Aspects of the Financial Soundness Indicators}

The financial soundness indicators are compiled to monitor the health of financial institutions. The soundness of financial institutions is also a key part of the infrastructure for strong macroeconomic performance and effective monetary policy at the national level. Hence, central banks are paying increasing attention to monitoring the health and efficiency of financial institutions, and to institutional developments that pose potential risks to financial stability (International Monetary Fund[IMF],2002). The monetary authority in Sudan has made a major effort to development and reform the banking system to complies with the IFSB guiding principles stressed on credit risk. Table (2) and figure (5) displays the soundness indicators of the financial performance of IBs in Sudan throughout 1997-2018. 
Table 2. Indicators of Sudan's Islamic Banks Financial Soundness (1997-2018)

\begin{tabular}{lcc}
\hline Year & $\begin{array}{c}\text { Return on Equity } \\
\text { (ROE) }\end{array}$ & $\begin{array}{c}\text { Nonperforming Loan (NPL) } \\
\text { (Standardized Ratio 4\%) }\end{array}$ \\
\hline 1997 & 53.5 & 15.1 \\
1998 & 18.1 & 15.6 \\
1999 & 65.6 & 23.0 \\
2000 & 41.6 & 16.0 \\
2001 & 9.20 & 17.0 \\
2002 & 42.6 & 13.0 \\
2003 & 41.2 & 11.0 \\
2004 & 61.1 & 9.00 \\
2005 & 67.3 & 7.00 \\
2006 & 19.2 & 19.0 \\
2007 & 21.0 & 17.0 \\
2008 & 22.8 & 15.0 \\
2009 & 24.6 & 15.1 \\
2010 & 26.5 & 14.1 \\
2011 & 28.8 & 12.6 \\
2012 & 36.5 & 11.9 \\
2013 & 29.6 & 8.40 \\
2014 & 33.7 & 7.10 \\
2015 & 37.1 & 5.10 \\
2016 & 46.1 & 5.20 \\
2017 & 48.0 & 3.30 \\
2018 & 94.7 & 3.20 \\
\hline
\end{tabular}

Source: CBOS, Annual Reports (1997-2018)

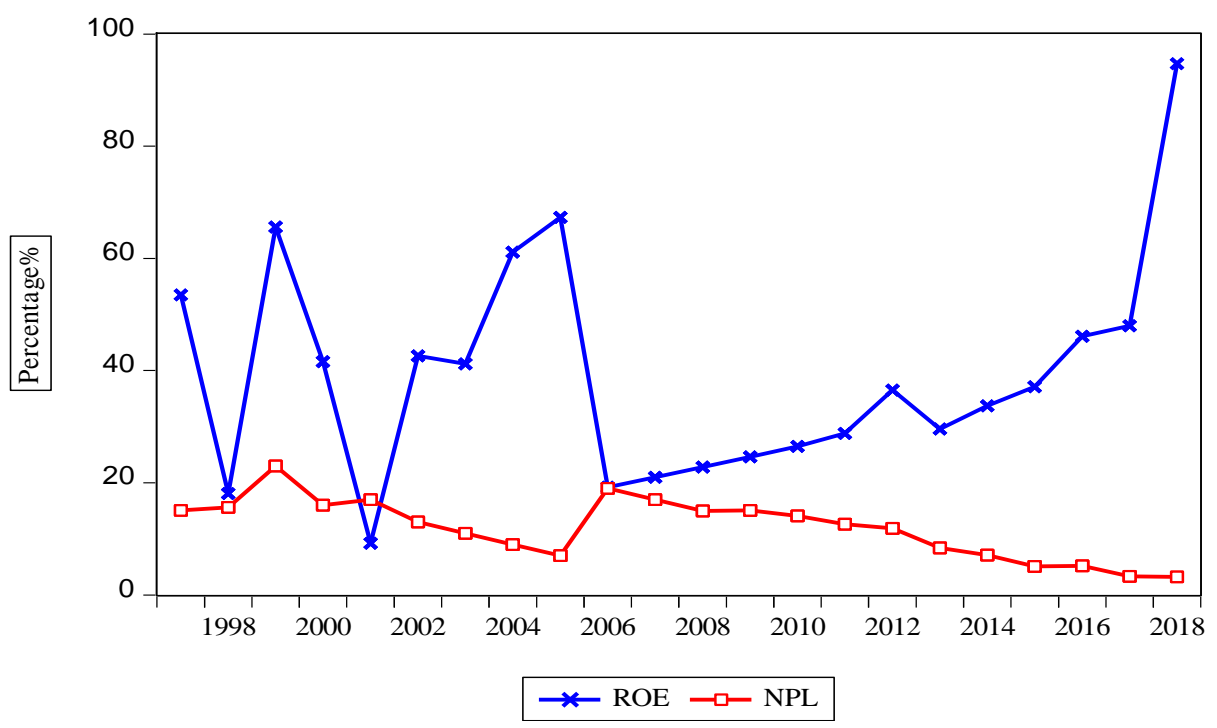

Figure 5. Indicators of Sudan's Islamic Banks Financial Soundness (1997-2018)

Source: Based on data in table 2

Some indications from table (2) and figure (5):

- The maximum value of ROE showed in the year 2018 of $94.7 \%$ while the minimum in the year 2001 of $9.2 \%$.

- The maximum value of NPL showed in the year 1999 of $23.0 \%$ while the minimum in the year 2018 of 3.2\%.

- Since 2017 NPL decreased markedly stating progress of the assets value and success of the monetary authority in its effort to fulfil the global indicator 4.0\%. Nevertheless, NPL was still under the Standardized Ratio 4\%.

- Tradeoff between ROE and NPL was reached in 2018, were ROE in its maximum value and NPL in its minimum value. In general, the best Banks's performance achieved in 2018 coincided with the minimum value of NPL. 


\subsection{Finance's Position of Islamic Banks in Sudan (1997-2018)}

\subsubsection{Contribution of Islamic Banks to the Development of Economic Sectors in Sudan}

The most vital role of Islamic Banks in economic and social development is to remove the deficiency of capital by stimulating saving and investment. A sound banking system mobilizes the small and scattered saving of the community, and makes them available for investment in productive enterprises. In this conception, the IBs perform two important functions:

- They mobilize deposits by offering attractive rate of return on investment deposits, thus converting saving, which otherwise would have remained inter, into active capital.

- They distribute these saving through the Islamic modes of finance among enterprises and different economic sectors which are connected with economic and social development. In this way, they promote the development of agriculture, trade and industry.

IBs in Sudan play an important role in achieving balanced development in different economic sectors. They transfer surplus funds or capital from the developed sectors to the less developed, where it is scarce and most needed. This reallocation or reorganization of funds between sectors will encourage economic development in underdeveloped parts of the country.

In Sudan finance is provided by IBs according to the economic activity and according to the Islamic mode of financing. Table (3) presents the flow of finance provided to different economic sectors as share of total gross finance. The banking finance includes finance extended by the operating banks to the private sector, public enterprises and to the state and local governments.

Table 3. Flow of Banking Finance to Economic Sectors (1997-2018)

\begin{tabular}{cccccccc}
\hline Year & Agriculture \% & $\begin{array}{c}\text { Industry } \\
\%\end{array}$ & $\begin{array}{c}\text { Local } \\
\text { Trade\% }\end{array}$ & $\begin{array}{c}\text { Foreign } \\
\text { Trade\% }\end{array}$ & $\begin{array}{c}\text { Transport and } \\
\text { Storage\% }\end{array}$ & $\begin{array}{c}\text { Energy and } \\
\text { Mining\% }\end{array}$ & $\begin{array}{c}\text { Real } \\
\text { Estate\% }\end{array}$ \\
\hline 1997 & 30.1 & 17.5 & 4.2 & 22.3 & 1.8 & 0.34 & 2.5 \\
1998 & 33.3 & 18.8 & 4.3 & 17.8 & 1.6 & 0.34 & 2.5 \\
1999 & 30.4 & 14.7 & 5.8 & 20.3 & 1.8 & 0.37 & 2.8 \\
2000 & 22.5 & 10.5 & 10.4 & 22.7 & 2.1 & 0.44 & 3.3 \\
2001 & 17.6 & 14.8 & 18.8 & 23.3 & 1.61 & 0.33 & 2.5 \\
2002 & 14.3 & 13.0 & 22.6 & 18.1 & 2.0 & 0.41 & 3.1 \\
2003 & 15.9 & 10.6 & 23.1 & 12.6 & 1.7 & 0.36 & 2.7 \\
2004 & 10.7 & 11.1 & 24.3 & 11.5 & 2.0 & 0.42 & 3.2 \\
2005 & 8.21 & 11.9 & 21.5 & 15 & 1.9 & 0.40 & 3.1 \\
2006 & 7.6 & 8.2 & 17.5 & 8.5 & 2.1 & 0.45 & 3.4 \\
2007 & 6.7 & 10.4 & 16.6 & 21.6 & 8.9 & 0.43 & 3.2 \\
2008 & 10.1 & 13.0 & 16.1 & 14 & 5.9 & 0.49 & 3.7 \\
2009 & 11.4 & 10.6 & 15.7 & 17.4 & 6.4 & 0.41 & 3.1 \\
2010 & 7.6 & 18.2 & 13.7 & 13.3 & 4.6 & 0.34 & 3.8 \\
2011 & 6.4 & 23.7 & 16.1 & 14.7 & 6.1 & 2.2 & 4.3 \\
2012 & 11.9 & 19.0 & 17.3 & 9.6 & 6.8 & 0.6 & 8.9 \\
2013 & 19.9 & 16.2 & 12.9 & 12.3 & 10.2 & 1.4 & 9.0 \\
2014 & 15.7 & 13.3 & 17.0 & 12.3 & 5.8 & 1.6 & 9.9 \\
2015 & 20.5 & 14.6 & 18.3 & 7.0 & 4.6 & 0.7 & 11.0 \\
2016 & 22.7 & 11.5 & 19.9 & 5.6 & 4.1 & 1.1 & 11.8 \\
2017 & 18.8 & 13.9 & 19.4 & 6.4 & 4.1 & 2.3 & 13.6 \\
2018 & 25.6 & 26.5 & 4.7 & 9.0 & 5.4 & 2.7 & 9.7 \\
Average & $\mathbf{1 6 . 7}$ & $\mathbf{1 4 . 6}$ & $\mathbf{1 5 . 5}$ & $\mathbf{1 4 . 3}$ & $\mathbf{4 . 2}$ & $\mathbf{0 . 8}$ & $\mathbf{5 . 5}$ \\
\hline
\end{tabular}

Source : CBOS (2007, p.138), CBOS (2008, p.40), CBOS (2018, p.221) 

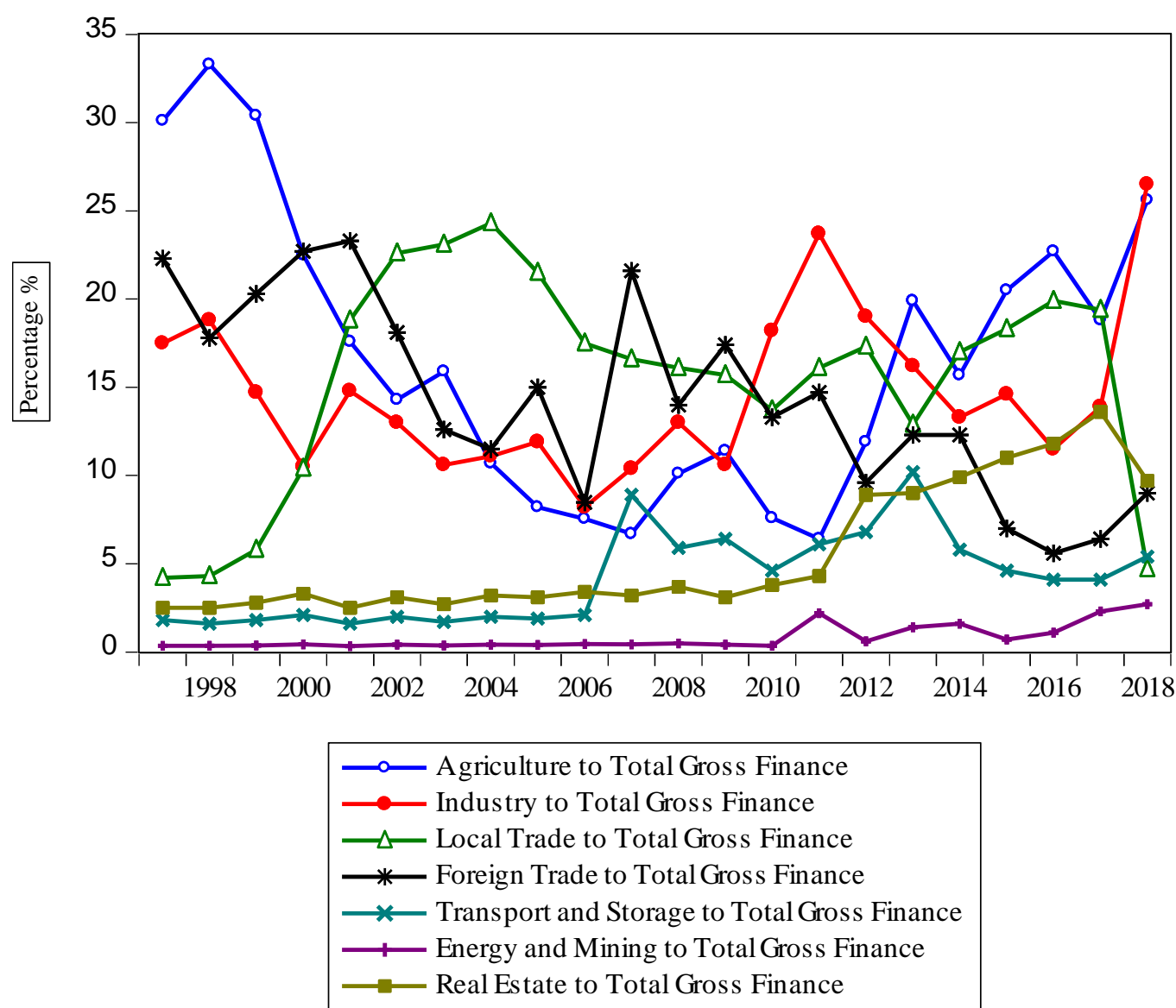

Figure 6. Flow of Banking Finance to Economic Sectors (1997-2018)

Source: Based on data in table3

As seen in table (3) and figure (6):

- During the period 1997-2018, banking finance directed to the agriculture sector ranged between (6.4\%-33.3\%). The highest was achieved in 2011 while the lower in 1998.

- Flow of banking finance to the Industrial sector ranged between $(8.2 \%-26.5 \%)$. The minimum percentage was achieved in 2006, whereas the maximum percentage reached in 2018.

- As for local trade sector, the finance ranged between (4.2\%-24.3\%). The smallest proportion achieved in 1997, whereas the maximum percentage reached in 2004.

- Foreign trade obtained finance fluctuated between (5.6\% in 2016-23.3\% in 2001).

- The finance bound for the Transport and Storage sector not exceed $10.5 \%$. The minimum percentage (1.6\%) was achieved in 1998.

- For all the period 1997-2010, the banking finance granted to the Energy and Mining sector not exceeding $1.0 \%$. But it was ranged between (0.6\%-2.7\%) during 2011-2018.

- The stream of banking finance to Real Estate sector ranged between (2.5\%-13.6\%) during 1997-2018.

- On average during the period 1997-2018, the finance granted to the Agriculture sector, Local Trade sector, Industrial sector, Foreign Trade sector, Real Estate sector, Transport and Storage sector and Energy and Mining sector is $16.7 \%, 15.5 \%, 14.6 \%, 14.3 \%, 5.5 \%, 4.2 \%$ and $0.8 \%$ respectively.

\subsubsection{Spreading of Finance through Islamic Modes (1997-2018)}

A way from interest rate or riba, IBs in Sudan have a various types of Islamic modes of finance (Murabaha Musharaka, Mudaraba, Salam, etc.). They use them to provide finance for individuals and economic sectors. Table (4) and figure (7) shows the distribution of finance through Islamic Modes during the period (1997- 2018). 
Table 4. Flow of Banking Finance by Islamic Modes (1997-2018)

\begin{tabular}{ccccc}
\hline Year & $\begin{array}{c}\text { Murabaha to Total } \\
\text { Gross Finance }\end{array}$ & $\begin{array}{c}\text { Musharaka to Total } \\
\text { Gross Finance }\end{array}$ & $\begin{array}{c}\text { Mudaraba to Total } \\
\text { Gross Finance }\end{array}$ & $\begin{array}{c}\text { Salam to Total Gross } \\
\text { Finance }\end{array}$ \\
\hline 1997 & 51.94 & 22.67 & 5.41 & 8.38 \\
1998 & 54.29 & 21.11 & 6.06 & 6.53 \\
1999 & 49.11 & 30.81 & 4.10 & 5.06 \\
2000 & 33.74 & 42.88 & 3.51 & 3.35 \\
2001 & 39.53 & 30.97 & 6.25 & 4.99 \\
2002 & 35.91 & 27.88 & 4.63 & 3.32 \\
2003 & 44.64 & 23.22 & 5.71 & 4.80 \\
2004 & 38.52 & 31.99 & 5.74 & 2.95 \\
2005 & 43.29 & 30.82 & 4.20 & 2.09 \\
2006 & 53.37 & 20.38 & 5.25 & 1.28 \\
2007 & 24.18 & 0.65 & 3.95 & 13.0 \\
2008 & 47.00 & 12.05 & 5.97 & 1.98 \\
2009 & 52.28 & 10.48 & 6.11 & 2.23 \\
2010 & 51.90 & 8.96 & 6.70 & 1.17 \\
2011 & 61.35 & 6.64 & 6.11 & 0.75 \\
2012 & 49.88 & 10.94 & 5.38 & 1.91 \\
2013 & 53.26 & 11.06 & 5.24 & 1.97 \\
2014 & 52.17 & 9.37 & 5.39 & 3.79 \\
2015 & 49.76 & 7.05 & 6.61 & 2.99 \\
2016 & 46.21 & 6.71 & 5.00 & 3.00 \\
2017 & 48.54 & 6.47 & 7.79 & 0.59 \\
2018 & 54.40 & 6.36 & 5.23 & 1.40 \\
Average & $\mathbf{4 7 . 1}$ & $\mathbf{1 7 . 2}$ & $\mathbf{5 . 5}$ & $\mathbf{3 . 5}$ \\
\hline
\end{tabular}

Source : CBOS (2007, p.138), CBOS (2008, p.40), CBOS (2018, p.221)

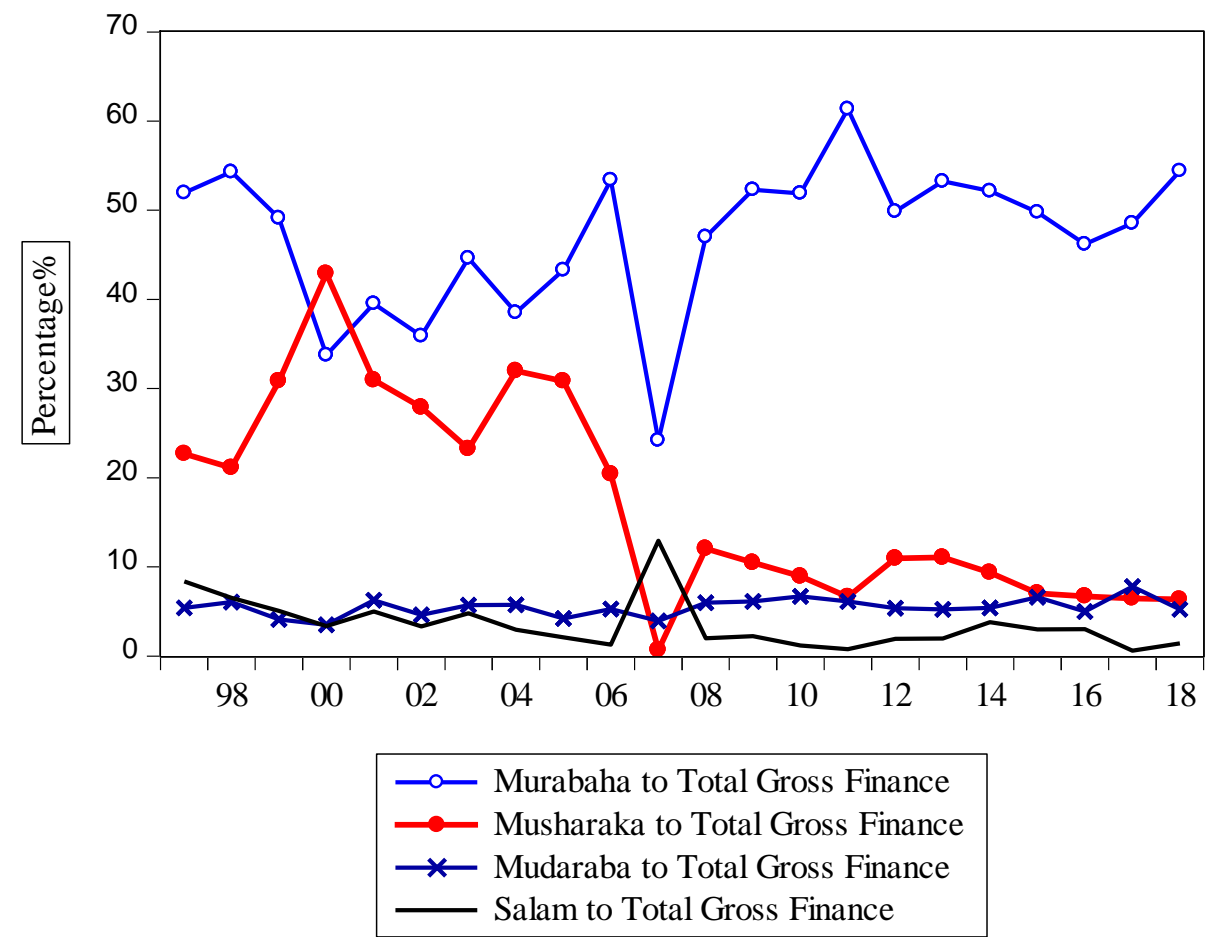

Figure 7. Flow of Banking Finance by Islamic Modes (1997-2018)

Source: Based on data in table 4

Signals from table (4) and figure (7):

- Provision finance by Murabaha mode ranged between (24.2\%-61.4\%), representing a clear indication that IBs focused finance to their clients by Murabaha mode touched of $54.4 \%$ by the close of the year 2018. It is believed that some of the reasons of preference and tendency of using Murabaha in Sudan can be related to: lower associated risks, easy to apply, easy to explain to clients and pre-known profits comparing to Mudaraba and 
Musharaka. Hence, this helps the bank to plan its cash flows, short-term financing compared to other modes, fast rate of working capital turnover and high demand by customers (COMCEC,2017, p.91).

- As for Musharaka, except the year 2000, it was ranged between (0.65\%-31.9\%).

- Granting finance in Mudaraba mode ranged between (3.5\%-7.8\%).

- Except for the year 2007, Salam finance ranged between (0.59\% in 2017- 8.38\% in 1997)

- On average during the period 1997-2018, the finance granted by Murabaha, Musharaka, Mudaraba and Salam is $47.1 \%, 17.2 \%, 5.5 \%$ and $3.5 \%$ respectively.

- It's worthy to comment that due to the intensive use of Murabaha mode, the CBOS (2002, p.18) issued a decree ordering all banks to decrease their transactions based on Murabaha to 30\% and to increase their dealings based on other modes. However, what's seen from table (4) is that still, Murabaha was intensively used (almost $54.4 \%$ ) by the end of 2018 .

\section{Experimental Analysis and Conclusions}

\subsection{Models Description}

To answer why do Sudan's Islamic Banks are concentrating finance in murbaha mode and its potential effects on the financial performance through the default risk might be occurrence, the following models will be applied:

\subsubsection{The Model(A)}

Its aimed to measures which one of Islamic modes of finance have more influence on the non-performing loans and then on the financial performance of IBs.

$$
\text { Nonperforming Loan }=f(\text { Murabaha, Musharaka, Mudaraba, Salam })
$$

Equation (1) implies that the nonperforming loans (NPL) is the function of granting finance in Islamic modes.

Equation (1) can be rewritten as follows:

$$
N P L=f(\text { Mur, } M u s h, \text { Mud, Slm) }
$$

Rearrangement of equation (2) in the estimated form as follows:

$$
\log (N P L)=\alpha_{0}+\alpha_{1} \log (\mathrm{Mur})+\alpha_{2} \log (\mathrm{Mush})+\alpha_{3} \log (\mathrm{Mud})+\alpha_{4} \log (\mathrm{Slm})+\varepsilon
$$

Where:

NPL: Nonperforming loans. It's a measure of asset quality or finance (in case the client has not made repayments of principal). When a bank is unable to recover NPL, it can repossess or sell assets pledged as collateral to collection agencies. Therefore, the growth of (NPL) designates a rise in credit risk and deterioration the quality of finance resulting in declining the financial performance of IBs (Ahmed, A.S., Takeda, C., \& Shawn, T., 1999). The sign for the relationship between NPL and granting finance in Islamic modes is predicted to be positive or negative. If the sign is a positive, it means that the increase of granting finance by Islamic modes will lead to an increase in NPL. May be due to the lack of quality of feasibility studies or procedures of granting finance like collaterals. Consequently, a high assets quality is projected to influence the productivity of the bank.

$\alpha 0$ : Intercept while $\alpha 1, \alpha 2, \alpha 3$ and $\alpha 4$ : Coefficients of independent variables or finance in Islamic modes.

Mur: Measures the credit risk in term of granting finance in Murabaha mode.

Mush: Measures the credit risk in term of granting finance in Musharaka mode.

Mud: Measures the credit risk in term of granting finance in Mudaraba mode.

Slm: Measures the credit risk in term of granting finance in Salam mode.

ع: Error term.

\subsubsection{The Model (B)}

It's designed to measures the effect of NPL on the financial performance of IBs in term of return on equity (ROE).

$$
\text { Financial performance }=f \text { (Nonperforming Loan) }
$$

Equation (4) involves that Banks's financial performance is a function in nonperforming loans.

Equation (4) can be rewritten as follows:

$$
R O E=f(N P L)
$$


The estimated equation of the model(B) is described in logarithmic form as follows:

$$
\log (R O E)=\beta_{0}+\beta_{1} \log (N P L)+\mu
$$

Where:

ROE: Return on Equity. Its measures the financial performance of IBs in terms of earnings and profitability of a business in relation to the equity. Because shareholder's equity can be calculated by taking all assets and subtracting all liabilities. ROE is also a metric of how well the company utilizes its equity to generate profits.

NPL: Already defined in the model (A).

$\beta 0$ : Intercept while $\beta$ 1: Coefficients of independent variable or nonperforming loans and $\mu$ : Error term.

Equation (6) suggests that, the predicted sign between ROE and NPL and FP is negative; because an increase of NPL indicates an increase in credit risk consequently worsening quality of finance resulted in declining ROE and negatively affecting the financial performance of IBs (Mustafa,2019, p.9)

For the purpose of the study, it is probably that interaction between equation (3) and equation (6) indicating that an expansion of granting finance in Murabaha mode may lead to increasing non-performing loans thus reduces the financial performance of IBs.

\subsection{Outcomes of the Test of Data Stationarity}

Data used to estimate of the models has been tested for unit root through applied the Augmented Dickey-Fuller (ADF) test, the results are stated in table (5).

Table 5. Unit Root Test Results

\begin{tabular}{|c|c|c|c|c|c|c|}
\hline \multicolumn{7}{|c|}{ Null Hypothesis: ROE has a unit root, Exogenous: Constant, Lag Length: 0} \\
\hline \multirow[t]{2}{*}{ Variable } & \multirow[t]{2}{*}{ ADF Statistic } & \multirow[t]{2}{*}{ Probability } & \multirow{2}{*}{$\begin{array}{l}\text { MacKinnon } \\
1 \%\end{array}$} & \multirow{2}{*}{$\begin{array}{l}\text { Critical } \\
5 \%\end{array}$} & \multirow{2}{*}{$\begin{array}{r}\text { Value } \\
10 \%\end{array}$} & \multirow[t]{2}{*}{ Decision At (5\%) } \\
\hline & & & & & & \\
\hline ROE & -3.1673 & 0.0114 & $-4.004425-3$. & 3.098896 & -2.690439 & Stationary \\
\hline NPL & -4.8351 & 0.0002 & -3.886751 & 3.052169 & -2.666593 & Stationary \\
\hline Mur & -4.6316 & 0.0003 & -3.886751 & 3.052169 & -2.666593 & Stationary \\
\hline Mush & -3.6497 & 0.0024 & -3.886751 & 3.052169 & -2.666593 & Stationary \\
\hline Mud & -3.5589 & 0.0029 & -3.886751 & 3.052169 & -2.666593 & Stationary \\
\hline Slm & -3.5589 & 0.0029 & -3.886751 & 3.052169 & -2.666593 & Stationary \\
\hline
\end{tabular}

Source: Own calculation

As show in table (5), the time series are stationary at first difference of 5\% MacKinnon Critical Value, these time series include; ROE, NPL, Mur, Mush, Mud and Slm.

\subsection{Models Estimation Results}

Table (6) illustration the results of projected parameters of the model(A) while table (7) display the results of the model(B). 
Table 6. Model(A)Estimation Results

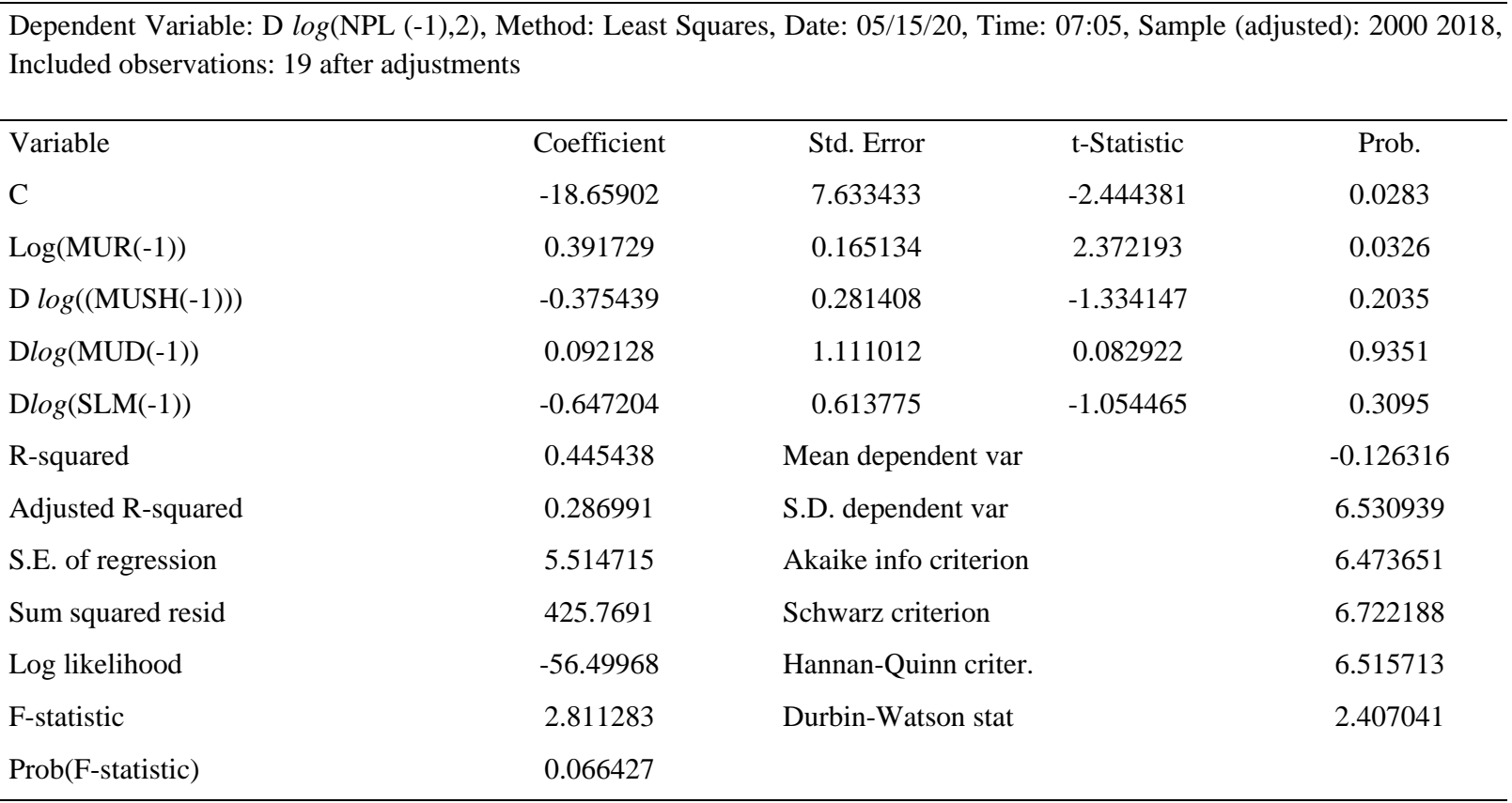

Source: Own calculation

Table 7. Model (B)Estimation Results

\begin{tabular}{lcccc}
\hline $\begin{array}{l}\text { Dependent Variable: } \log (\mathrm{ROE}) \\
\text { observations: } 22\end{array}$ & Method: Least Squares, Date: 05/15/20 & Time: 07:23, Sample: 1997 & 2018, Included \\
\hline Variable & Coefficient & Std. Error & t-Statistic & Prob. \\
C & 59.01307 & 7.633433 & -2.444381 & 0.0000 \\
Log(NPL) & -1.628698 & 0.165134 & 2.372193 & 0.0419 \\
R-squared & 0.191043 & Mean dependent var & 39.49091 \\
Adjusted R-squared & 0.150595 & S.D. dependent var & 19.94941 \\
S.E. of regression & 18.38601 & Akaike info criterion & 8.747565 \\
Sum squared resid & 6760.909 & Schwarz criterion & 8.846751 \\
Log likelihood & -94.22322 & Hannan-Quinn criter. & 8.770931 \\
F-statistic & 4.723179 & Durbin-Watson stat & 1.664473 \\
Prob(F-statistic) & 0.041946 & & \\
\hline
\end{tabular}

Source: Own calculation

\section{Discussion of the Results}

As express in table6, the estimated results of the model (A) showed that except the MUR variable, the explanatory variables (MUSH, MUD and SLM) insignificant because they have probability more than (0.05).

The value of the Adjusted R- Squared is very low representative that the explanatory variables are able to interpret almost $28 \%$ of gross changes in nonperforming loan(NPL) of IBs. The whole test of regression is approximately important because, the value of F- statistic of (2.811283) with probability of $(0.066427)$.

The measurement of MUR seeming with a positive signal and carry a probability of 0.03 showing that a growing of granting finance by means of murabaha may lead to increase the nonperforming loan, if a costumer be ineffective to make suitable payment or become unable to repay the principal, the credit risk will take place and the profitability will be reducing. But in practice IBs liquidate collaterals to cover loss.

As for the parameter of the MUSH mode, the estimation shown a negative sign and a weak impact on the 
nonperforming loan (probability of 0.2035 ) suggesting that a one percent increase in granting finance by Musharaka mode would probably lead to reduction the nonperforming loan by $(0.37)$ percent thus, improvement of the financial performance of IBs.

The predicted factor of MUD shown a positive mark and it carry probability of (0.9351) implying that the increase in granting financing via Mudaraba mode by one percent would possibly lead to rise the nonperforming loan by (0.092) percent because the silent partner (the bank) has no tool to manage the investment or to enter into the management of the project. The bank may expose to entire loss of its investment (the amount advanced to the entrepreneur).

The forecasted result of SLM shown a negative sign and it has probability of (0.3095) demonstrating that a one percent upsurge in granting finance through Salam mode maybe lead to cut the nonperforming loan by $(0.64)$ percent accordingly the financial performance will be enhanced.

On the other hand, as seen in table7 the estimated results of the model(B) displayed that the explanatory variable (NPL) is significant because it has likelihood below (0.05). Adjusted R- Squared is low indicating that the nonperforming loan interpret about $15 \%$ of total changes in return on equity (ROE) of IBs. The test of overall regression is good because, F- statistic have value of (4.723179) with probability under the value of $(0.05)$ that is (0.041946).

The sign of the NPL, appeared in the estimated results with inverse sign in its relations to the performance of banks and it has probability of (0.0419) involving that a reduction in the nonperforming loan will lead to enhancement of ROE by (1.6) percent. Therefore, the reduction of NPL indicates a decline in credit risk, good utilization of fund and high quality of finance.

The final result is that the expansion of granting finance through the Murabaha mode maybe leads to an increased probability of credit risk and nonperforming loan, resulted in lowering the return on equity and the financial performance of banks. However, IBs reduced the credit risk associated with Murabaha through sell funded assets or liquidating collateral in the occurrence of a customer's nonpayment. This explain why Islamic Banks concentrating finance in Murabaha Mode?

\section{Conclusions}

The main reason for the expansion granting finance by Murabaha mode is that Islamic banks are heavy rely on collaterals, therefore, in case of customer's default, they liquidate or sell assets related to Murabaha contract thus reduces the impact of credit risk on the financial performance. But if market value of collaterals less than the value of finance granted to clients, banks are likely exposed to credit risk as a result of expansion. So, the results found significant positive relationship between the nonperforming loans and provision finance by both Murabaha and Mudaraba modes. Whereas were a negative with both Musharaka and Salam. Moreover, it is found that there is strong negative relationship between nonperforming loans the finance performance of Islamic banks in terms of Return on Equity. Although Murabaha mode acquired on more than $47 \%$ of gross finance on average, the study observes decreasing trend in NPL (1997-2018) indicating that Sudan's Islamic banks in general are away from credit risk but they are not totally protected. This agreed with Boffey and Robson $(1995$, p. 66) if credit risk is not well managed, it can lead to failure. As a result, for any bank to succeed, its credit risk management must be handled with a lot of seriousness because loss sure will occur, the bank will have to "extend its hands" to get funds from other modes of finance to meet up or cover the losses. On the other hand, failure to reduce risk of concentration finance in Murabaha showing that the monetary authority in Sudan (the Central Bank of Sudan) inefficiency distributing the finance between various modes and economic sectors where finance granted to Agriculture sector on average not exceed $16.7 \%$ of total gross finance and thus Islamic banks need to paying more attention to agriculture and small scale industries because the majority of the population in Sudan in rural areas.

\section{Recommendations and Policy Implications}

To reduce the risk of concentration finance by murabaha mode, the monetary authority need to advice Islamic banks to diversify and distribute their finance among all Islamic modes. Also, they must not completely depend on collaterals collected from their clients to cover risk of expansion of finance by murabaha mode. Because if client fails to fulfil payment and market value of collaterals dropped compared to the principal finance, credit risk take place thus the financial performance will be reducing. In this way, the study suggested that the Central Bank of Sudan need to implement the following procedures in its annual financing policy: Firstly, reducing the Murabaha margin, secondly: imposing certain procedural conditions on the application of Murabaha in order to make it difficult for the banks and unattractive to the clients, thirdly: keeping Islamic banks aware with the risk associated with Islamic modes especially murabaha in light of the requirements of IFSB and BCBS and 
fourthly: a periodical review of the Banks's statistical reports related to share of the Murabaha consequently, imposition of sanctions on the undisciplined banks.

Islamic banks have a limited capacity to absorb the potential losses of murabaha finance. This loss could be covered by using income or return generated through other modes. So, a correct management of Islamic modes of finance is very important and vital.

Since 1993, the US government has imposed economic sanctions on Sudan resulted in secession of South Sudan in July 2011. As result of secession, Sudan loss of $75 \%$ of its oil revenues. Agriculture continues to employ about $80 \%$ of the labor force, therefore the study strongly recommends Islamic banks to increases granting finance to this sector in order to improve GDP growth.

\section{References}

AAOIFI. (2010). Sharī'ah standards for Islamic financial institutions, Standard No. 30, Bahrain. Retrieved from https://aaoifi.com/shariaa-standards/?lang=en

Abdul, A. (1999). Islamic Business Contracts: Agency Problem and the Theory of the Islamic Firm. International Journal of Islamic Financial Services, 1(2), 1-15. Retrieved from http://iaif.ir/images/khareji/articles/other/46.pdf

Abdullah, M., Shahimi, S., \& Ghafar Ismail, A. (2011). Operational Risk in Islamic Banks: Examination of Issues. Qualitative Research in Financial Markets, 3(2), 131-151. https://doi.org/10.1108/17554171111155366

Ahmed, A. S., Takeda, C., \& Shawn, T. (1999). Bank Loan Loss Provision: A Re-examination of Capital Management and Signalling Effects. Journal of Accounting and Economics, 28(1), 1-25. https://doi.org/10.1016/S0165-4101(99)00017-8

Alharbi, A. (2015). Development of the Islamic Banking System. Journal of Islamic Banking and Finance, 1(3), 12-25. https://doi.org/10.15640/jibf.v3n1a2

Alsadek, H., \& Andrew, C. (2007). A primer on islamic finance: Definitions, sources, principles and methods. This article was originally published at University of Wollongong-Research, School of Accounting and Finance, Working Paper Series No. 07/05. Retrieved from http://ro.uow.edu.au/commpapers/341

BCBS. (2001). Risk management practices and regulatory: Cross-sectional comparison. Retrieved from $\mathrm{http} / / \mathrm{www} \cdot$ bis.org

Boffey, R., \& Robson, G. N. (1995). Bank Credit Risk Management. Managerial Finance, 21(1), 66-78. https://doi.org/10.1108/eb018497

CBOS, (2007). Annual report. Retrieved from https://cbos.gov.sd/en/content/annual-report-2007

CBOS, (2008). Аnnual report. Retrieved from https://cbos.gov.sd/en/content/annual-report-2008

CBOS, (2018). Annual report. Retrieved from https://cbos.gov.sd/ar/content/2018

CBOS, Annual reports for the period (1997-2001).

COMCEC. (2017). Diversification of islamic financial instruments. Retrieved from www.sbb.gov.tr/wp-content/uploads/2018/11/Diversification_of_Islamic_Financial_Instruments.pdf

Elgadi, E. M. (2016). Assessing the financial performance of Islamic banking: The case of Sudanese banks. Retrieved from

https://repository.uel.ac.uk/download/bc6f3b8698e0ba44a0c9d4703bea529370eb6b2e66bc925af479d28443 00693d/2635754/Assessing\%20the\%20Financial\%20Performance\%20of\%20Islamic\%20Banking\%20The $\% 20$ case $\% 20$ of $\% 20$ Sudanese $\% 20$ banks.pdf.

Grassa, R. (2018). Islamic banks' income structure and risk: Evidence from GCC countries. https://doi.org/10.2139/ssrn.1733018

Hassan, M. K., \& Eric, G. (2010). Faith-Based Ethical Investing: The Case of Dow Jones Islamic Indexes. Islamic Economic Studies, 17(2). https://doi.org/10.2139/ssrn.1808853

IFSB \& ISRA. (2016). Shari'ah non-compliance risk in the banking sector: Impact on capital adequacy framework of Islamic banks. Working paper series No.5. Retrieved from https://www.ifsb.org/press_full.php?id=334\&submit=more

IFSB. (2005). Guiding principles of risk management for Islamic financial institutions (Other than Insurance Institutions) Offering only Islamic financial services (IIFS), Definition and profiles of operational risk. Retrieved from https://www.ifsb.org/published.php 
IFSB. (2012). Guiding principles on liquidity risk management for institutions offering Islamic financial services. Retrieved from https://www.ifsb.org/published.php

IMF. (2002). Financial soundness indicators: Analytical aspects and country practices. Retrieved from https://www.imf.org/external/pubs/nft/op/212/

Iqbal, Z., \& Mirakhor, A. (2011). An Introduction to Islamic Finance: Theory and Practice. Asia: John Wiley \& Son Pte Ltd. https://doi.org/10.1002/9781118390474

Ismal, R. (2017). Assessing Moral Hazard Problem in Murabahah Financing. Journal of Islamic Economics, Banking and Finance, 5(2), 101-112. Retrieved from https://ibtra.com/pdf/journal/v5_n2_article5.pdf

Kireyev, A. (2001). Financial reforms in sudan: Streamlining bank intermediation. Retrieved from https://www.elibrary.imf.org/view/IMF001/02400-9781451847383/02400-9781451847383/02400-9781451 847383_A001.xml?lang=en\&language $=$ en\&redirect=true

Loghod, H. (2005). Do islamic banks perform better than conventional banks? Evidence from gulf cooperation council countries. Retrieved from http://www.arab-api.org/images/publication/pdfs/297/297_wps1011.pdf

Mansour, I., \& Sa'adeh, Y. (2016). Evaluating Murabaha in Islamic Banks. INTERNATIONAL JOURNAL FOR INNOVATION EDUCATION AND RESEARCH, 4(6), 184-190. Retrieved from https://www.ijier.net/ijier/article/view/573/486

Mehmet, S. (2008). Islamic Banking and Finance: Social Failure. New Horizon, 169, 1-3. Retrieved from http://ssrn.com/abstract=1735674

Mohsin, M. I. (2005). The Practice of Islamic Banking System in Sudan. Journal of Economic Cooperation, 26(4), 27-50. Retrieved from https://www.sesric.org/files/article/82.pdf

Moussa, F., \& Zaiane, S. (2018). Risk Determinants of Islamic Banking in the Mena Countries during the Global Financial Crisis and the Arab Spring Period: A Search for Empirical Evidences. International Research Journal of Finance and Economics, 170, 8-26. Retrieved from http://www.internationalresearchjournaloffinanceandeconomics.com/ISSUES/IRJFE_170_01.pdf

Mustafa, O. A. O. (2019). Assessment of the Financial Performance of Islamic Commercial Banks in Sudan under Credit Risk and Inflation Pressures (1995-2017). Journal of Islamic Banking and Finance, 7(1), 14-26. https://doi.org/10.15640/jibf.v7n1a2

Nedal, E. (2004). Islamic banking's role in economic development: Future outlook. Centre of Islamic finance, Bahrain Institute of Banking and Finance. Retrieved from https://www.semanticscholar.org/paper/Islamic-Banking-'-s-Role-in-Economic-Development

Nouman, M., Karim, U. K., \& Gul, S. (2018). Why Islamic Banks Tend to Avoid Participatory Financing? A Demand, Regulation, and Uncertainty Framework. Business \& Economic Review, 10(1), 1-32. https://doi.org/10.22547/BER/10.1.1

Rosly, S. A. (2005). Critical issues of islamic banking and financial market: Islamic economics, banking and Finance, investment, takaful and financial planning. United States: Author house.

Samad, A., Gardner, N., \& Cook. (2005). Islamic Banking and Finance in Theory and Practice: The Experience of Malaysia and Bahrain. The American Journal of Islamic Social Sciences. https://doi.org/10.35632/ajiss.v22i2.458

Swartz, N. P. (2012). Risk Management in Islamic Banking. African Journal of Business Management, 7(37), 3799-3809. Retrieved from http://www.academicjournals.org/AJBM

Walkshausl, C., \& Sebastian, L. (2012). Islamic Equity Investing: Alternative Performance Measures and Style Analysis. Journal of Investing, 21(4), 182-189. https://doi.org/10.3905/joi.2012.21.4.182

Warde, I. (2010). Front matter in Islamic finance in the global economy. Edinburgh: University Press. Retrieved from

https://www.cambridge.org/core/books/islamic-finance-in-the-global-economy/BCD13D47457FE83FB475 09C43A101C01

\section{Copyrights}

Copyright for this article is retained by the author(s), with first publication rights granted to the journal.

This is an open-access article distributed under the terms and conditions of the Creative Commons Attribution license (http://creativecommons.org/licenses/by/4.0/). 